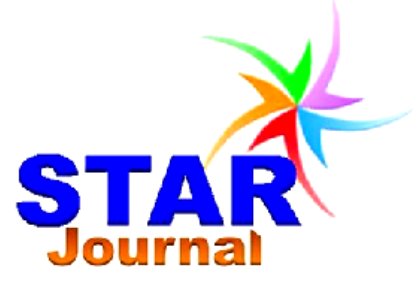

ISSN: 2226-7522(Print) and 2305-3327 (Online) Science, Technology and Arts Research Journal April-June 2012, 1(2):108-116 www.starjournal.org Copyright $\odot 2012$ STAR. All Rights Reserved

Original Research

\title{
Impact of Sidewalk Business Enterprise in Sustaining Urban Livelihoods in Southern Ethiopia
}

\begin{tabular}{|c|c|}
\hline \multicolumn{2}{|l|}{ Habtamu Tolera } \\
\hline \multicolumn{2}{|c|}{$\begin{array}{c}\text { College of Social Sciences, Department of Geography and Environmental Studies, Post Box No: 395, } \\
\text { Wollega University, Nekemte, Ethiopia }\end{array}$} \\
\hline Abstract & Article Information \\
\hline \multirow{3}{*}{$\begin{array}{l}\text { The main purpose of this study has been to identify and draw attention to the } \\
\text { situation of vendors and vendor activities in the study area. It attempted to } \\
\text { provide a picture of the future trajectory of vending as informal economic } \\
\text { activity. In order to achieve this objective a sample of } 140 \text { street vendors were } \\
\text { selected and relevant data were gathered and analyzed. The findings of the } \\
\text { study revealed a variety of vendor activities. The study also revealed that the } \\
\text { majority of street vendors joined sidewalk business due to economic hardships } \\
\text { in their lives and to provide sustenance for themselves and their dependent } \\
\text { families. Vending on street provides livelihood, source of additional income } \\
\text { and temporary employment to the urban poor and relatively cheap goods for } \\
\text { low income group urban population. }\end{array}$} & $\begin{array}{l}\text { Article History: } \\
\text { Received }: 26-04-2012 \\
\text { Revised } \quad: 22-06-2012 \\
\text { Accepted }: 27-06-2012 \\
\end{array}$ \\
\hline & $\begin{array}{l}\text { Keywords: } \\
\text { Vending } \\
\text { Informal Economy } \\
\text { Livelihood Strategy } \\
\text { Urban Poor } \\
\text { Hawker }\end{array}$ \\
\hline & $\begin{array}{l}\text { *Corresponding Author: } \\
\text { Habtamu Tolera } \\
\text { E-mail: habtol@yahoo.com }\end{array}$ \\
\hline
\end{tabular}

\section{INTRODUCTION}

As in many African countries, in Ethiopia too, the urban poor, unemployed and underemployed loomed large in the major cities and towns. According to ILO, (2000) cited in Adno, (2000) the annual average growth rate of the labor force in the country ranged from $2.3 \%$ between 1995 and 1990 to $2.4 \%$ between 1991 and 2000 while the rate of population growth during the same periods were $3 \%$ and $3.3 \%$ respectively. Although a large increase is envisaged in both cases, the latter increase is faster than the former implying continued and increasing gap between the demand and supply of labor. Turning to the rate of urban unemployment in the country, it was $8 \%$ in 1984 and $21.2 \%$ in 1992 and climbed to about $23 \%$ by 2004 , three times that of the 1984 (CSA, 1984 and 2004). The formal sector cannot solve this unprecedented unemployment problem. In contrast, the informal sector has become by far the largest employer in urban centers since the 1980 s recession. The labor absorptive capacity of the sector by far exceeds that of the medium and large-scale industries. It has been more than eleven fold $(1,149,500$ persons) to that of the medium and large-scale industries (101,259 persons) making up over $50 \%$ of the total employment (CSA, 2004 and 2004b).

A more recent study of Central Statistical Authority (CSA) 2004 reported over 1 million urban informal employments in the country and this accounts for $48.3 \%$ of the economically active urban population. Hawassa having roughly 70 thousand population (CSA, 1994) is estimated to hold over 27 thousand of informal sector participants (Zerihun, 2005; CSA, 2003), which are $39 \%$ of the total population of the town. In spite of large proportion of operators in the informal sector in general and street vending in particular, much emphasis has not yet been given to this urban economic units. As street vending seems to be permanent features of Ethiopia urban economy, there is an urgent need to formulate an explicit and comprehensive policy towards vendor activities. However, now there is very little information on the status and the role street vendors play in economic development and service delivery in Ethiopia and not at all in Hawassa. This is due to the absence of well-conducted research work on street vending and lack of disaggregated data on the operators, which makes it impossible to estimate the share of street vendors in the informal sector in the area 
under investigation. So the provision of information on vendors and their customers to urban planners and policy makers might help them formulate longterm policy towards vendors in the country in general and in the study area in particular.

\section{MATERIALS AND METHODS}

\section{Description of Study Area}

Hawassa, the capital of the newly delineated Southern Nations and Nationalities and Peoples Regional State (SNNPRS), is located at $07^{\circ} 03^{\prime}$ North latitudes and $30^{\circ} 29^{\prime}$ East longitudes. It is found along the international road that connects Addis Ababa, Ethiopia with Nairobi at 275 kilometers south of Addis Ababa. The town is bounded by Lake Hawassa in the west, Oromia regional state in the North and Alamura Mountain in the South and Hawassa Zuria Wereda in the East. The town emerged in 1960 as a small village along the shores of Lake Hawassa and designated as the capital town of Sidamo Administrative Region two years later by Emperor Haile ellasie the first. However, since 1992, the town has become the socio-economic and political center of SNNPRS.

\section{Sampling, Data Collection and Analysis}

The target population for the survey is street vendors of Hawassa Town. According to the information obtained from the City Administration of Hawassa, there is no complete record of street vendors. So, the researcher constructed sampling frame through a census method. Static and semi-static vendors were enumerated in terms of the types of enterprises they operate. A total of 438 vendors were found to be engaged in different enterprises and then manageable sample population was determined as $32 \%$ of a total giving a sample size of 140 . Hence, sample vendors were drawn using a stratified random sampling procedure and proportional sampling fraction. The former was used because the population to be sampled was heterogeneous while the latter was preferred to obtain sample number that was proportional to each stratum size in the population. Eventually, representative respondents were randomly selected and approached for interview.

Table 1: Coverage of sample vendors by types of activities.

\begin{tabular}{lccc}
\hline Types of activities (Industry) & Sample Frame & Sample Size & \% Share \\
\hline Prepared food & 50 & 16 & 11.0 \\
Secondhand clothes & 104 & 33 & 24.0 \\
Bicycle service & 129 & 41 & 29.0 \\
Fruits and vegetables & 74 & 24 & 17.0 \\
Household goods & 39 & 13 & 9.0 \\
Miscellaneous activities & 42 & 13 & 10.0 \\
\hline \multicolumn{1}{c}{ Total } & $\mathbf{4 3 8}$ & $\mathbf{1 4 0}$ & $\mathbf{1 0 0 . 0}$
\end{tabular}

The main body of information, primary data, was collected through questionnaire to the street vendors. It contains details of vendors' sociodemographic aspects; details of the economic aspects of vendor operations and the nature of linkages exist in terms of initial capital, credit, wage, purchase, sale and labor mobility with other sectors and the major challenges faced vendor operators. The questionnaire was carefully designed and structured based on the objective of the study. Ten interviewers were selected on the bases of their personal characteristics and educational level (all are high school graduates). They were given a two days training on the nature and details of the questionnaire as well as on the procedures they should follow while conducting the interview. A pilot survey consisting of 15 vendors $(11 \%$ of the total sample) was conducted to pretest the questionnaire before embarking on the survey.
In some cases, however, the secondary data sources also referred. The secondary data used in this study were different official documents like books, proceedings, journals, various publications, web sites, etc on the subject of informal sectors and street vending. The sources were from various organizations such as ILO/JASPA and various departments and libraries of Addis Ababa University, etc.

Both qualitative and quantitative methods of data analysis were used. The first stage of data analysis comprised the preparation of code books for the questionnaires. The questionnaires were edited, coded, and analyzed using the (SPSS) computer programs. The quantitative techniques utilized in this study were cross tabulations and frequency $\%$ ages. Tables, figures and graphs were used to show the results of the analysis and to facilitate the interpretation of the data. 


\section{RESULTS AND DISCUSSION}

\section{Socio-Demographic Features of Vendor Respondents}

As the survey result reveals, vending operations were a particularly important source of employment and income for youths. The majority of the respondents $(82.9 \%)$ were in youth age structure, i.e. between 16-30 years. Furthermore, some $15.0 \%$ vendor entrepreneurs aged 31 years and above and the remaining $2.1 \%$ were aged between 11-15 years old.

Vending industry was a particularly important source of employment and income for both gender groups. About $67.1 \%$ of the entrepreneurs were males and $32.9 \%$ were females. Hence, males' representation was higher than females. On the other hand, there were some interesting inter-firm variations with respect to enterprise owners. In Hawassa, $79.2 \%$ of total enterprise owners in fruit and vegetable, $81.2 \%$ in prepared food and $61.5 \%$ in household goods hawking were females. Females were also significant in miscellaneous types of vendor activities such as charcoal selling, cosmetics selling, shoe vending, etc. Such informal income generating activities gave women a special way to escape social and cultural restrictions by strengthening their economic status in the households or outside when divorced or separated or unmarried in the city surveyed.

The survey found out that, out of the 140 vendor entrepreneurs interviewed, $59.3 \%$ enterprise owners were single, $30 \%$ married, $5 \%$ widowed and 5.7 were divorced. This evidence clearly indicates vending permits unmarried, married, widowed and divorced population to generate jobs and income with small capital outlay, little skill and education in the area surveyed. According to Central Statistical Authority (1994) report on the marital status of Hawassa city, $37.4 \%$ were married, $4.3 \%$ widowed, $53.1 \%$ single and $5.3 \%$ divorced. This evidence is almost confirming the marital status of the survey result in the study area. Closer examination of the data in table also suggests that in almost all enterprises, most of the enterprise owners were single. This implies that vendor activities represent mainly survival strategies adopted in the face of growing unemployment and underemployment aiming at raising incomes for own support so as to alleviate hunger and poverty. Secondly, this fact is in case when vendors have tried some to strengthen their economic base and stock to support themselves and other burdens/ dependents before marriage.
Out of 140 sampled vendors interviewed, $15.4 \%$ had (1-2) children, $12.2 \%$ (3-4), 7.1\% (56 ), and some $5.7 \%$ of respondents had (7-8) children. Thus, the owners had relatively large family members whose livelihoods depend on informal sources of income. This evidence, therefore, suggests the significance of urban informal employment, in this case of street vending. The rest, also the overwhelming majority $(59.3 \%)$, cited no children. They were sole proprietors. However, they had rather extended family and other dependents. This implies that vending was not only providing cash income to sustain the livelihood of vendors themselves and their immediate family but the enterprise also important for the survival of their extended families in the households and other dependents from somewhere else in the households.

When we come to types of ethnicity, out of 140 sampled respondents interviewed, 30.0 per cent, and $25.0 \%$ were the Wolayita and the Guraghe ethnic groups respectively. The two were the known vendor entrepreneurs in the city understudy. The two groups alone constituted over half of the total sample employment. Other ethnic groups such as Tigraway, Hadiya, Kambata, and Gedeo were insignificant in number $(7.1 \%)$ in the study area. Turning to specific vendor activities, the Guraghe groups dominated several of the street entrepreneurships. $56 \%, 48.4 \%$, and $38.4 \%$ of vendors in prepared food, secondhand cloth, and household goods enterprises were respectively the Guraghes. A recent survey reinforces these evidences. For instance, according to Tebarek (1997), the predominance of this ethnic group in trade-oriented activities was consistent with the culture of the people that induced both geographical mobility and entrepreneurial activity.

Education is one of the most important social aspects. The level of education influences productivity, in this cases the productivity of vendor activities. It was a key determinant factor of entrepreneurial activities, primarily, to develop the ability and technical skills of entrepreneurships to improve the productivity of the work force and the level of firms' performance and their vertical proliferations (Kassahun, 2000) low. From overall 140 respondents, $87.1 \%$ were literate whereas $12.9 \%$ were illiterate. From this available evidence, one can observe that vending employments in study area were indeed substantial. This is the fact that vending activities played an important role in proffering employment and income for broad masses of urban literates such as school leavers, school attendees, technical school graduates and some illiterates. 
Habtamu Tolera

The study area was overwhelmingly considered to hold impoverished rural migrants who flocked to the urban informal sector for urban street vending. A great proportion of respondents (75.7 $\%$ ) were found to be from outside Hawassa while only $24.3 \%$ were city-born. The major push factor of village to town migration was probably the scarcity of farmland due to population pressure and the drudgery associated with traditional
Sci. Technol. Arts Res. J., April-June 2012, 1(2):108-116

farming for very low returns in rural setting. The recent increasingly growing importance of the town as a socio-economic and political center of the SNNPRS was also considered as pull factor for migrants from both rural and urban areas. The amalgam of these factors mainly attracted large proportion of population from the city's hinterland and other urban centers (Figure 1).

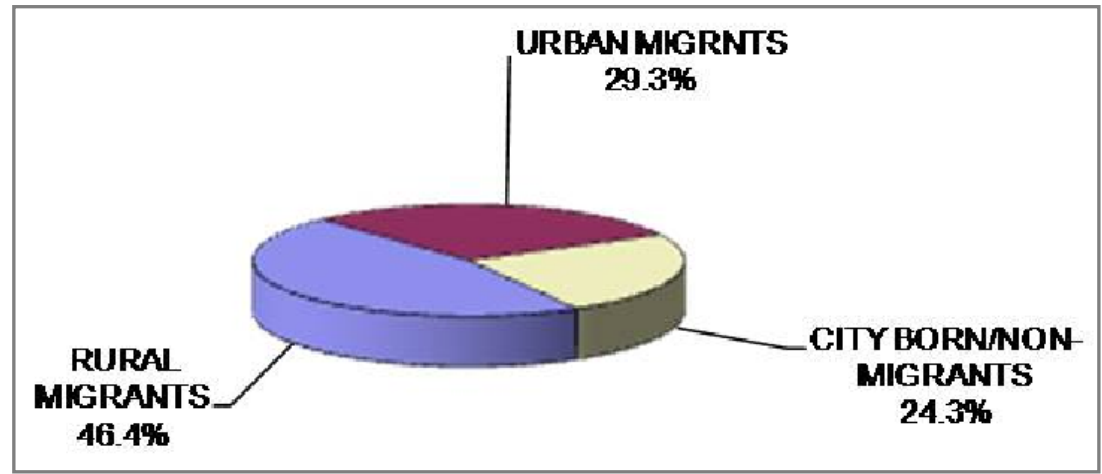

Figure 1: Migrant vendor respondents by rural and urban settings.

Over all, Figure1 depicts the growing importance of street vending incomes in sustaining urban livelihood of rural migrants, urban migrants, and city-born individuals and households in the study town According to the finding, $50.7 \%$ of the respondents reported migration to the city to look for employment. In support of this evidence, Todaro (1986) stated that the migrants' main reason to move to towns would be directly related to the probabilities of finding a job. Some $16.4 \%$ mentioned to meet parents /relative/ friends, $6.5 \%$ to go to school, and only $2.1 \%$ cited city-attraction as the main reason for coming to the study town.

Table 2: Vendors by types of activities and their reasons for coming to the town.

\begin{tabular}{|c|c|c|c|c|c|c|c|c|c|c|c|c|c|c|}
\hline \multirow{2}{*}{$\begin{array}{l}\text { Reasons for } \\
\text { Migration }\end{array}$} & \multicolumn{2}{|c|}{$\begin{array}{l}\text { Fruits and } \\
\text { Vegetables }\end{array}$} & \multicolumn{2}{|c|}{$\begin{array}{l}\text { Second } \\
\text { Hand } \\
\text { Clothes }\end{array}$} & \multicolumn{2}{|c|}{$\begin{array}{l}\text { Bicycle } \\
\text { Service }\end{array}$} & \multicolumn{2}{|c|}{$\begin{array}{l}\text { Prepared } \\
\text { Food }\end{array}$} & \multicolumn{2}{|c|}{$\begin{array}{c}\text { House } \\
\text { Hold } \\
\text { Goods }\end{array}$} & \multicolumn{2}{|c|}{$\begin{array}{c}\text { Miscellane } \\
\text {-ous } \\
\text { Activities }\end{array}$} & \multicolumn{2}{|c|}{ Total } \\
\hline & No & $\%$ & No & $\%$ & No & $\%$ & No & $\%$ & No & $\%$ & No & $\%$ & No & $\%$ \\
\hline Employment & 9 & 37.5 & 23 & 69.8 & 26 & 63.5 & 2 & 12.5 & 5 & 38.4 & 6 & 46.1 & 71 & 50.7 \\
\hline Meet Parents & 1 & 4.2 & 1 & 3.0 & 9 & 22.0 & 6 & 37.5 & 3 & 23.1 & 3 & 23.1 & 23 & 16.4 \\
\hline $\begin{array}{l}\text { To go to } \\
\text { school }\end{array}$ & 2 & 8.3 & 1 & 3.0 & 1 & 2.4 & 3 & 18.8 & 1 & 7.7 & 1 & 7.7 & 9 & 6.5 \\
\hline City-attraction & 1 & 4.2 & - & - & 2 & 4.8 & - & - & - & - & - & - & 3 & 2.1 \\
\hline Non-migrants & 11 & 45.8 & 8 & 24.2 & 3 & 7.3 & 5 & 31.2 & 4 & 30.8 & 3 & 23.1 & 34 & 24.3 \\
\hline Total & 24 & 100 & 33 & 100 & 41 & 100 & 16 & 100 & 13 & 100 & 13 & 100 & 140 & 100 \\
\hline
\end{tabular}

\section{Economic Aspects of Vendors Business Venture}

The informal sector is heterogeneous in character and comprises a wide variety of activities. There were even distinct differences among the vendor operations in terms of the major commodity or service groups sold or delivered (Sethruaman, 1997; De Soto, 1989; McGee, 1986). Vendor entrepreneurs in
Hawassa at "Piassa and Menaheria" areas also belonged to this group. They engaged in a variety of types of street based activities and offered different kinds of goods or services to the community at low cost. Table 3 shows types of vendor activities and their importance in terms of number of operators employed and types of goods or service they sold or delivered to pedestrian customers, individuals and 
households, as well as data in Table 3 clearly shows vending activities are different in kind and bicycle services and secondhand cloth selling were by far the predominant activities in the study area.

Table 3: Vendors by types of their business operations.

\begin{tabular}{lcc}
\hline \multicolumn{1}{c}{ Types of Firms } & Frequency & $\begin{array}{c}\text { \%age Share of } \\
\text { Vendor Operators }\end{array}$ \\
\hline Bicycle services & 41 & 29.0 \\
Secondhand clothes & 33 & 24.0 \\
Fruits and vegetables & 24 & 17.0 \\
Prepared food & 16 & 11.0 \\
Household goods & 13 & 9.0 \\
Miscellaneous activities & 13 & 10.0 \\
\hline \multicolumn{1}{c}{ Total } & $\mathbf{1 4 0}$ & $\mathbf{1 0 0 . 0}$ \\
\hline
\end{tabular}

The dominant form of ownership in the street occupation was consistently individual proprietorship. In the study area, as data in Table 4 reveal, $94.3 \%$, almost exclusively, were organized under sole ownership. About $4.3 \%$ of vendors' establishments were family ownership while the remaining $1.4 \%$ was operated as partnership ownership.

Table 4: Percentage of vendors by types of activities and ownership pattern.

\begin{tabular}{lccccccc}
\hline $\begin{array}{c}\text { Ownership } \\
\text { Pattern }\end{array}$ & $\begin{array}{c}\text { Fruits } \\
\text { and } \\
\text { Vegetable }\end{array}$ & $\begin{array}{c}\text { Second } \\
\text { Hand } \\
\text { Cloths }\end{array}$ & $\begin{array}{c}\text { Bicycle } \\
\text { Service }\end{array}$ & $\begin{array}{c}\text { Prepared } \\
\text { Food }\end{array}$ & $\begin{array}{c}\text { House } \\
\text { hold } \\
\text { goods }\end{array}$ & $\begin{array}{c}\text { Miscellan } \\
\text {-eous } \\
\text { Activities }\end{array}$ & Total \\
\hline Sole ownership & 91.7 & 96.9 & 92.7 & 100 & - & 92.3 & 94.3 \\
Family Own & 8.3 & - & 7.3 & - & 92.3 & 7.7 & 4.3 \\
Partnership & - & 3.1 & - & - & 7.7 & - & 1.4 \\
$\quad$ Total & $\mathbf{1 0 0}$ & $\mathbf{1 0 0}$ & $\mathbf{1 0 0}$ & $\mathbf{1 0 0}$ & $\mathbf{1 0 0}$ & $\mathbf{1 0 0}$ & $\mathbf{1 0 0}$ \\
\hline
\end{tabular}

When specific vendor activities viewed independently, the pattern was analogues with the above situation. For instance, in second hand clothes sole ownership accounted for $96.9 \%$ of the total sampled population. The corresponding proportion for prepared food, bicycle service, miscellaneous activities and fruit and vegetable operations were $100.0 \%, 92.7 \%, 92.3 \%$ and $91.7 \%$ respectively. In contrast, there was no sole ownership enterprise owner in household good business operation. The majority of household goods vending (92.3\%) ownerships were the family and the remaining $7.7 \%$ were partnership ownership.

The survey found out that self-employed operators represented $67.1 \%$ of the street business employment, i.e. over two-thirds of vendor activities were what would be termed as a single person-operated enterprises and about $32.9 \%$ of them were ran by $2-3$ persons. The cases of the latter types, owners were asked to state their relationships with their business operations. Accordingly, $73.9 \%$ were found to be unpaid family workers, $23.9 \%$ were paid employees, and $2.2 \%$ were unpaid apprentices. Thus, employment in the street occupation in study area held working proprietors/selfemployed, unpaid family workers, unpaid apprentices and paid employees. Clearly, in the vendor context, street activities represent mainly survival strategies adopted in the face of growing unemployment. The evidence seems to support the widely held view that the majority of the urban labor force is self-employed. It reinforces the importance of self-employment in sustaining livelihood in the further urban labor profile. The majority of labors employed were migrants from rural labor work especially agriculture. Some were school leavers, graduates from technical schools and retrenched workers due to the collapse of previous occupations. 
Table 5: Vendors by types of activities and sources of their skills training.

\begin{tabular}{|c|c|c|c|c|c|c|c|c|c|c|c|c|c|c|}
\hline \multirow[t]{2}{*}{$\begin{array}{l}\text { Source } \\
\text { of Skills }\end{array}$} & \multicolumn{2}{|c|}{$\begin{array}{c}\text { Fruit and } \\
\text { Vegetabl } \\
\text { e }\end{array}$} & \multicolumn{2}{|c|}{$\begin{array}{l}\text { Second } \\
\text { Hand } \\
\text { Cloth }\end{array}$} & \multicolumn{2}{|c|}{$\begin{array}{l}\text { Bicycle } \\
\text { Service }\end{array}$} & \multicolumn{2}{|c|}{$\begin{array}{c}\text { Prepared } \\
\text { Food }\end{array}$} & \multicolumn{2}{|c|}{$\begin{array}{l}\text { House } \\
\text { hold } \\
\text { Goods }\end{array}$} & \multicolumn{2}{|c|}{$\begin{array}{l}\text { Miscellan } \\
\text {-eous } \\
\text { Activities }\end{array}$} & \multicolumn{2}{|c|}{ Total } \\
\hline & No & $\%$ & No & $\%$ & No & $\%$ & No & $\%$ & No & $\%$ & No & $\%$ & No & $\%$ \\
\hline Self-taught & 17 & 70.8 & 23 & 69.7 & 29 & 70.7 & 10 & 62.4 & 4 & 30.8 & 5 & 38.4 & 88 & 62.9 \\
\hline Formal Training & - & - & - & - & - & - & - & - & - & - & - & - & - & - \\
\hline $\begin{array}{l}\text { Apprentice } \\
\text { Programme }\end{array}$ & 5 & 20.8 & 8 & 24.2 & 12 & 29.3 & 3 & 18.8 & 5 & 38.4 & 3 & 23.2 & 36 & 25.7 \\
\hline Family & 2 & 8.4 & 2 & 6.1 & - & - & 3 & 18.8 & 4 & 30.8 & 5 & 38.4 & 16 & 11.4 \\
\hline Total & 24 & 100 & 33 & 100 & 41 & 100 & 16 & 100 & 13 & 100 & 13 & 100 & 140 & 100 \\
\hline
\end{tabular}

Level of training background and skills acquired over the years influence the income level of vendor respondents. The source of knowledge and the level of training background of informal sector operators were affected not only by technical and production aspects but also by the questions of management and organization. Their links with formal training institutions were very low (Bagchaw 1993; UNECA, 1993). The survey result reinforces this evidence.

The predominant position of skill acquisition in street vending was self-taught/personal effort, i.e. $62.9 \%$ of vendor entrepreneurs had acquired their skills by teaching themselves. The second most important method of skill acquisition was through the informal apprentice programme/ on job training, i.e. learning by observing and assisting other workers. This was the fact that apprentice was a cost effective because it combines learning with work. In study area, the total number of respondents that acquired their skills using this method was $25.2 \%$. Therefore, with regard to links with training institutions, it was noted that a vast majority of the vendor entrepreneurs (over 88\%) obtained their training using these two methods. Turning to specific activities, these methods were typically the most skill acquisition methods in bicycle service and fruit and vegetable operations. Furthermore, some $11.4 \%$ of the sampled respondents cited family as source of their skill training. Surprisingly, no vendor obtained formal training that had a direct relevance with his/her present hawking profession in study area. This implies poor links with formal training institutions and the absence of government attentions to help vendors in their course of struggle against hunger and poverty through planned interventions such as training. Therefore formal training should be required because the lack of such training in marketing and technical skills perhaps influence the productivity and work efficiency of vendor businesses in the area surveyed.

The study result also investigates the longevity of vendors in vending profession in study area. Accordingly, the largest proportion of vendors $(75 \%)$ characterized by recent entrants who hawked 4 years and below. Some 20\% hawked between 5 and 10 years. This shows that huge numbers of street operators joined the business in a very recent past.

The study reveals vendors modes of payments to obtain goods or services for their stalls. The majority of vendors $(69.3 \%)$ paid for their goods or services sold by cash. Some $21.4 \%$ of respondents obtained on consignment/ agreement while $7.9 \%$ mentioned credit as their main mechanisms to receive of goods or services from sources. The remaining $1.4 \%$ used several of these approaches such as cash and credit, cash and consignment, etc.

So, the evidence shows that most vendors preferred to pay for their goods or services by cash and keeps a low volume of stock. This is because they hoped to sell their stock quickly and therefore purchase their goods or services for the next day to earn immediate cash to sustain daily living. The root cause for supplying of low volume of stock is primarily vendors' low capital base to invest on large stocks and even lack of stores to secure this stock. Consignment/ contract/ was the second most important modes of obtaining inputs next to cash payments.

According to Ethiopian labor law, the average working hours a day for all class of workers is 8 hours (Mulat, 1989). Based on this information if it is assumed that 48 ( $8 \mathrm{hrs}$ a day, 6 days a week) hours per week represents full time employment, then $85.7 \%$ of the vendor entrepreneurs in vending activities can be considered full time while about $14.3 \%$ worked less than 8 hours per 
Habtamu Tolera

day (less than 48 hours/week), i.e. they spent less than full time.

As survey result indicated, out the 140 sampled entrepreneurs, the larger proportion of vendors $(52.2 \%)$ mentioned selling at discount as their major adaptive mechanism to attract clients/markets. This goes in line with the opinions of the customers in the study area. This means that the lower price of vendors' goods or services was the major motives that pull them to the vendor markets .About $21.4 \%$ said calling for their goods or services together with price as
Sci. Technol. Arts Res. J., April-June 2012, 1(2):108-116

their best method to sell the major part of their sales/stock. A small $0.7 \%$ used other approaches such as selling by credits, provision of quality goods or services, and the like. Over all, the common mechanism vendors adopted in study area to sell the major part of their sales or to reduce intense market competition was lowering their profit margins substantially. The fact that vendors' competition did not only provide food, clothes, household goods, etc at cheaper prices which make up the largest share of poor people budget but it was important for the survival of the poor with limited purchasing power.

Table 6: Vendors by types of activities and level of their initial capital.

\begin{tabular}{|c|c|c|c|c|c|c|c|c|c|c|c|c|c|c|}
\hline \multirow{2}{*}{ Birr } & \multicolumn{2}{|c|}{$\begin{array}{l}\text { Fruit and } \\
\text { Vegetable }\end{array}$} & \multicolumn{2}{|c|}{$\begin{array}{c}\text { Secondh } \\
\text { and } \\
\text { Cloth }\end{array}$} & \multicolumn{2}{|c|}{$\begin{array}{l}\text { Bicycle } \\
\text { Service }\end{array}$} & \multicolumn{2}{|c|}{$\begin{array}{l}\text { Prepared } \\
\text { Food }\end{array}$} & \multicolumn{2}{|c|}{$\begin{array}{c}\text { House } \\
\text { hold } \\
\text { Goods }\end{array}$} & \multicolumn{2}{|c|}{$\begin{array}{c}\text { Miscellan } \\
\text { eous } \\
\text { Activities }\end{array}$} & \multicolumn{2}{|c|}{ Total } \\
\hline & No & $\%$ & No & $\%$ & No & $\%$ & No & $\%$ & No & $\%$ & No & $\%$ & No & $\%$ \\
\hline$\leq 100$ & 11 & 45.8 & 6 & 18.2 & 10 & 24.3 & 13 & 81.3 & 4 & 30.8 & 6 & 46.1 & 50 & 35.7 \\
\hline $101-250$ & 5 & 20.9 & 10 & 30.2 & 12 & 29.3 & 1 & 6.2 & 5 & 38.4 & 3 & 23.1 & 36 & 25.7 \\
\hline $251-500$ & 8 & 33.3 & 10 & 30.2 & 7 & 17.1 & - & - & 3 & 23.1 & 3 & 23.1 & 31 & 22.2 \\
\hline $501-1000$ & - & - & 7 & 21.2 & 12 & 29.3 & 2 & 12.5 & 1 & 7.7 & 1 & 7.7 & 23 & 16.4 \\
\hline Total & 24 & 100 & 33 & 100 & 41 & 100 & 16 & 100 & 13 & 100 & 13 & 100 & 140 & 100 \\
\hline
\end{tabular}

As Table 6 explains, about $35.7 \%$ of vendor entrepreneurs reportedly started with initial capital of Birr 100 and below. Some $25.7 \%$ incurred Birr 101-250 while 22.2\% had between Birr $251-500$. Only $16.4 \%$ of the total surveyed vendors started their business with Birr 501 and above. The low level of initial capital requirements was typical of this economy. One possible explanation for such low level of investment situation was the absence of reliable resources of capital finance.

Table 7: Vendors by types of activities and their present capital.

\begin{tabular}{|c|c|c|c|c|c|c|c|c|c|c|c|c|c|c|}
\hline \multirow{2}{*}{ Birr } & \multicolumn{2}{|c|}{$\begin{array}{c}\text { Fruits } \\
\text { and } \\
\text { Vegetable }\end{array}$} & \multicolumn{2}{|c|}{$\begin{array}{l}\text { Secondh } \\
\text { and } \\
\text { Cloth }\end{array}$} & \multicolumn{2}{|c|}{$\begin{array}{l}\text { Bicycle } \\
\text { Service }\end{array}$} & \multicolumn{2}{|c|}{$\begin{array}{l}\text { Prepared } \\
\text { Food }\end{array}$} & \multicolumn{2}{|c|}{$\begin{array}{c}\text { House } \\
\text { Hold } \\
\text { Goods }\end{array}$} & \multicolumn{2}{|c|}{$\begin{array}{l}\text { Miscellan } \\
\text { eous } \\
\text { Activities }\end{array}$} & \multicolumn{2}{|c|}{ Total } \\
\hline & No & $\%$ & No & $\%$ & No & $\%$ & No & $\%$ & No & $\%$ & No & $\%$ & No & $\%$ \\
\hline$\leq 100$ & 5 & 20.8 & 14 & 42.4 & 7 & 17.1 & 2 & 12.5 & - & - & 3 & 23.1 & 31 & 22.1 \\
\hline $101-250$ & 4 & 16.7 & 3 & 9.1 & 10 & 24.4 & 2 & 12.5 & 3 & 23.1 & 4 & 30.8 & 26 & 18.5 \\
\hline $251-500$ & 13 & 54.2 & - & - & 22 & 53.3 & 7 & 43.8 & 8 & 61.5 & 3 & 23.1 & 53 & 38.0 \\
\hline $501-1000$ & 2 & 8.3 & 16 & 49.5 & - & - & 3 & 18.7 & 3 & 18.7 & - & - & 22 & 15.7 \\
\hline $1001-5000$ & - & - & - & - & 2 & 4.9 & 2 & 12.5 & 2 & 12.5 & 3 & 23.1 & 8 & 5.7 \\
\hline Total & 24 & 100 & 33 & 100 & 41 & 100 & 16 & 100 & 13 & 100 & 13 & 100 & 140 & 100 \\
\hline
\end{tabular}

Table 7 shows that, out of 140 respondents, $22.1 \%$ had current capital of Birr 100 and below, $18.5 \%$ between Birr 101-250, 38\% between Birr $251-500$, and the remaining $21.4 \%$ would have a capital by far between Birr 501-5000. The general picture of this survey reveals the improvement of vendors' income /current capital over that of the level of initial capital. Some street vendors have shifted their capital from lower levels to higher levels. For instance, the number of vendors who had an initial capital between Birr 251-500 gets increased from 31 (or $22.2 \%$ ) to 53 (or $37.9 \%$ ) 


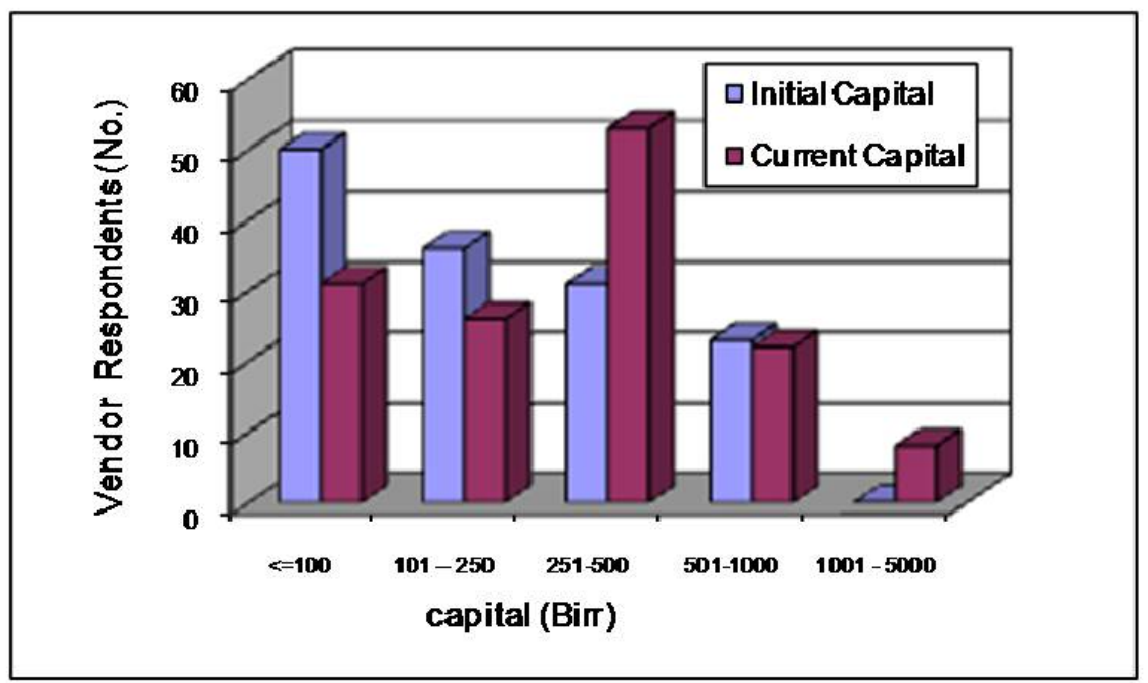

Figure 2: Initial capital versus current capital.

and another important point is that even the current capital of 8 vendors (or $5.7 \%$ ) out stripped Birr 1000 and adds another new income category beyond that of initial capital level (Figure 2).

We asked about whether their income was satisfying to them in fulfilling the basic needs of their family and other dependents, the majority $(60.7 \%)$ would reply it was not enough while $39.3 \%$ said it was better. The former were also asked how did they bridge a gap. Then, 37.2\% mentioned that they had a support from friends/ relatives, $15.5 \%$ reported careful management /saving of what they would get, $7.2 \%$ noted that the family generated other incomes and $4.1 \%$ reported selling of assets for survival.

In nutshell, half $(50.8 \%)$ of street vendors spend about Birr 250 and below while the remaining half $(49.2 \%)$ Birr 251 and above. In his informal and closer discussion with respondents, a researcher examined that vendors expend much larger money than what they claimed to be their income. Most of the money they earned were spent on fulfilling basic needs of their families such as food, clothing, house rent and school fees, which make up the largest share of their monthly earnings. To them, vending represents mainly survival strategies adopted to avoid unemployment and to earn a subsistence income.

\section{CONCLUSIONS}

The study identified different types of vendor activities. These are fruits and vegetables, secondhand clothes, bicycles services, prepared food, household goods and miscellaneous activities. These street enterprises provide some advantages to the town's economy and population by performing major role in the sale and distribution of foodstuffs and other commodities or in delivering urban services. Vending for bicycle service and secondhand clothes were by far the predominant activities. They alone absorbed $53 \%$ of the total sampled vendor operators and delivered a variety of goods or services for low income individuals and households.

The survey reveals that the majority of street vendors $(82.9 \%)$ were concentrated in the young age group between 16 and 30 years. It is an age group when youths were either married or were preparing to marry to set up own family apart from parents stock. Thus, street vending would be an attractive alternative to these youths than waiting for employment in urban modern sector units, which are at best in very limited and short supply, and again which are highly competitive seeking out more educated and skilled persons than they are. It is also found that street vending was a particularly important source of employment and income for both sexes. Male's representation was $67.1 \%$, higher than females, Vending enterprises were dominated by single/ unmarried vendor entrepreneurs (59.3\%). This implies that vendor activities represent mainly survival strategies adopted in the face of growing unemployment and underemployment aiming at raising incomes for own support so as to alleviate hunger and poverty. Secondly, this fact is in case when vendors have tried some to support themselves and other economic burdens/ dependents and to strengthen their economic base and stock before marriage. 
Habtamu Tolera

The dominant ethnic groups flocked to street vending occupation were wolayita (30\%) and Guraghe $(25 \%)$. In terms of specific types of vendor activities, the Guraghe group dominated several activities. It was found that informal street business was closely linked to migration in the study area. Almost half of respondents (46.4\%) were of rural origin while $29.3 \%$ were urban migrants. The remaining $24.3 \%$ were city-born. Vending on street provides livelihood, source of additional income and temporary employment to the urban poor and relatively cheap goods for low income group urban population. In this context, the country should develop an integrated informal sector policy which frequently promotes and transfers these sectors into formal enterprises for the overall socio economic development of the country.

\section{REFERENCES}

Bagachwa, M.D. and Lauanga. (1993). The state and the informal sector in Tanzania. ILO/JASPA, Addis Ababa.

Central Statistical Authority. (1984). Population and Housing Census of Ethiopia, Addis Ababa.

Central Statistical Authority. (1994). Population and Housing census of Ethiopia, Addis Ababa.

Central Statistical Authority. (1996). Report on urban informal sector sample survey; statistical bulletin, 174, Addis Ababa.

Central Statistical Authority (2000). Report on urban informal sector sample survey, statistical bulletin, 319, Addis Ababa.

Central Statistical Authority. (2000). The 1994 Population and Housing census of Ethiopia, Volume 1, statistical report, Addis Ababa.

Central Statistical Authority. (2004a). Urban biannual employment unemployment survey, volume 319 , statistical bulletin, Addis Ababa.

Central Statistical Authority. (2004b). Report on large and medium scale manufacturing and electricity industrial survey statistical bulletin, Volume321. Addis Ababa.

De Soto, H. (1989). The Other Path, Harper and Row New York.

International Labor Office. (1972). Employment, income and equality: strategies for increasing productivity in Kenya, Geneva.

International Labor Office. (1984). The informal sector in Africa: synthesis and country summaries, Addis Ababa.

International Labor Office. (1985). Informal sector in Africa, Addis Ababa.

International Labor Office. (1991). The dilemma of the informal sector. International Labor Conference, $78^{\text {th }}$ sessions, Geneva.
Sci. Technol. Arts Res. J., April-June 2012, 1(2):108-116

International Labor Office. (1992). African employ report.

International Labor Office. (1993). Ethiopia towards sustained employment promotion, Addis Ababa.

International Labor Office. (1997/98). World labor report: Industrialization, democracy and social stability, Geneva.

Kassahuun Argaw. (2000). The urban informal sector in Nazareth Town: The case of women petty traders in "Gimb Gebeya," unpublished M.A. thesis, Deportment of Geography, Addis Ababa University, Addis Ababa.

McGee, T. (1986). On the utilization of dualism: The informal sector and Mega urbanization in developing countries. $R D D$ 17(1): 83-94.

Sethuramen, S.V. (1976). The urban informal sector: Concepts, measurement and policy. ILO, Geneva.

Sethuramen, S.V. (1977). The Urban informal sector in Africa.

Sethuramen, S.V. (1981). The role of urban informal sectors in Sethuraman (ed.): The urban informal sector in developing countries. Employment, poverty and environment. ILO, Geneva.

Sethuramen, S.V. (1997). Urban poverty and the informal Sector: A critical assessment of current strategies. ILO, Geneva. (Online), available at http://www.ilo.org/public/english/employment/recon/e iip/publ/1998/urbpover.htm

Tebarek Leka. (1997). Employment and Income in Urban Informal Sector: The Case of Shoe Enterprises in "Wereda" 5 at Merkato Area.

Teshome Adno (2000). Unemployment in Addis Ababa: Trends, level and differentials. unpublished M.A. Thesis; Department of Demography, Addis Ababa University, Addis Ababa.

Mulat Tehome. (1986). The average working hours a day for all class of workers in Ethiopia.

Todaro, P. M. (1986). International migration, domestic unemployment and urbanization: A three-sector model, New York.

UNECA. (1993). Creating of enabling environment for the informal sector in Ethiopia, Addis Ababa.

UNECA. (2002). The development of micro finance industry in Ethiopia: performance, problems and prospects in Gebrehiowt Ageba, Jemal Mohammed and Solomon Tesfaye (Eds): Policy reform, implementation and outcome in Ethiopia. Addis Ababa.

Zerihun Dido (2005). Informal business sector inventory and analysis in "kebele" 06, Higher (1) of Hawassa. 